\title{
New species of Alpaida (Araneae, Araneidae) from Rondônia, Brazil
}

\author{
André A. Nogueira \& Stefan R. Dias
}

Departamento de Zoologia, Instituto de Biociências, Universidade de São Paulo, Rua do Matão, Travessa 14, n 321, $05508-900$ São Paulo SP, Brazil. (andrearanhas@gmail.com, srd_bio@hotmail.com)

\begin{abstract}
We described a new species of spider, Alpaida clarindoi sp. nov. (Araneidae), from the southwestern Amazon forest. The new species is distinguished from most Alpaida by the presence of a pair of shoulders spines. Females can be separated from similar species by the subquadrangular shape of the epigynum, and males by the shape of the terminal apophysis and the tegulum, which possess an apical pointed tip. Alpaida clarindoi sp. nov. is described based on both sexes.
\end{abstract}

KEYWORDS. Spiders, Arachnida, Taxonomy, Neotropical Region.

RESUMO. Nova espécie de Alpaida (Araneae, Araneidae) de Rondônia, Brasil. Nós descrevemos uma nova espécie de aranha, Alpaida clarindoi sp. nov. (Araneidae), da região sudoeste da floresta amazônica. A nova espécie se distingue das demais pela presença de um par de espinhos dorsais na parte anterior do abdome. A fêmea difere de espécies semelhantes pelo formato subquadrangular do epígino, e o macho pelo formato da apófise terminal e do tegulum, que possui um espinho apical na borda. Alpaida clarindoi sp. nov. é descrita com base em exemplares de ambos os sexos.

PALAVRAS CHAVE. Aranhas, Arachnida, Taxonomia, Região Neotropical.

Araneidae is the third most speciose spider family within Araneae, with close to 3,100 described species (World Spider Catalog, 2015). The Neotropical genus Alpaida O. Pickard-Cambridge, 1889 stands out as one of the largest within the family, with more than 140 known species (World Spider Catalog, 2015). The genus was extensively revised by LEVI (1988), which described 94 new species.

Since the revision, ten contributions were made to the taxonomy of the genus, including the transfer and redescription of Alpaida tullgreni (Caporiacco, 1955) (LEVI, 1993), the description of five males and one female of species previously known only from one sex (BUCKUP \& Meyer, 1993; Rodrigues \& MendonçA, 2011), and the description of 12 new species (ABRAHIM \& BONALDO, 2008; Santos \& Santos, 2010; Buckup \& Rodrigues, 2011; Braga-Pereira \& Santos, 2013; Deza \& Andia, 2014; Dierkens, 2014; SATURnino et al., 2015). In this paper we described a new species of Alpaida based on both sexes. This species was collected along of the Madeira River margins, in the southwestern border of the Brazilian Amazon. Spider sampling was part of a fauna monitoring campaign due to the construction of the Jirau hydroelectric power plant.

\section{MATERIAL AND METHODS}

The description of the species was based on 14 females and two males collected in Porto Velho, Rondônia, Brazil, from 2010 to 2013. Collections were made in three different localities along the Madeira River margins, Caiçara (9॰26’21.034”'S; 6447’32.165”'W), Abunã (9०41'50.017'S; 65'21'16.207'W) and Mutum

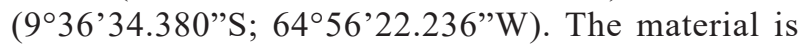

deposited in the arachnological collection of the Museu de Zoologia da Universidade de São Paulo (MZSP; curator R. Pinto-da-Rocha).

The description and terminology of the genitalia follows LEVI (1988). Images were made with a stereoscopic microscope Leica M125 coupled with a digital camera Leica DFC290. Images were taken at various focal planes and assembled to mount a multifocal image using software Leica Application Suite v3.3.0. All measurements are in millimetres.

\section{Alpaida clarindoi sp. nov.}

(Figs 1-9)

Type material. Holotype ${ }^{\lambda}$, Abunã (941'50.017'S; $65^{\circ} 21^{\prime} 16.207^{\prime}$ 'W), Porto Velho, Rondônia, Brazil, 09.VIII.2013, F. U. Yamamoto leg. (MZSP 56933). Paratypes. ㅇ, 28.II.2010, M. C. Silveira leg. (MZSP 34045); ㅇ, 28.II.2010, A. A. Nogueira leg. (MZSP 34046); ㅇ, 01.IX.2011, A. A. Nogueira leg. (MZSP 39196); ㅇ, 12.III.2011, A. A. Nogueira leg. (MZSP 40219); + , 09.VI.2011, S. Outeda-Jorge leg. (MZSP 40860); 우 31.I.2012, M. C. Silveira leg. (MZSP 45652); ㅇ, 14.VII.2012, R. Indicatti leg. (MZSP 50408); ㅇ, 14.VII.2012, R. Indicatti leg. (MZSP 50436); 웅 15.VII.2012, A. A. Nogueira leg. (MZSP 50489); ㅇ, 30.IX.2012, M. C. Silveira leg. (MZSP 53830); ㅇ, 06VIII-2013, S. Outeda-Jorge leg. (MZSP 56493), all from Caiçara (9²6'21.034”'S; 6447'32.165”'W). +, 15.XI.2010, R. Y. Lemos leg. (MZSP 37265); , 23.VIII.2011, S.

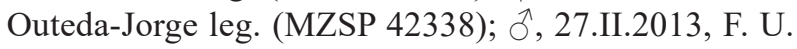
Yamamoto leg. (MZSP 55402); + , 28.II.2013, S. OutedaJorge leg. (MZSP 55580), all from Abunã (941'50.017’'S; 

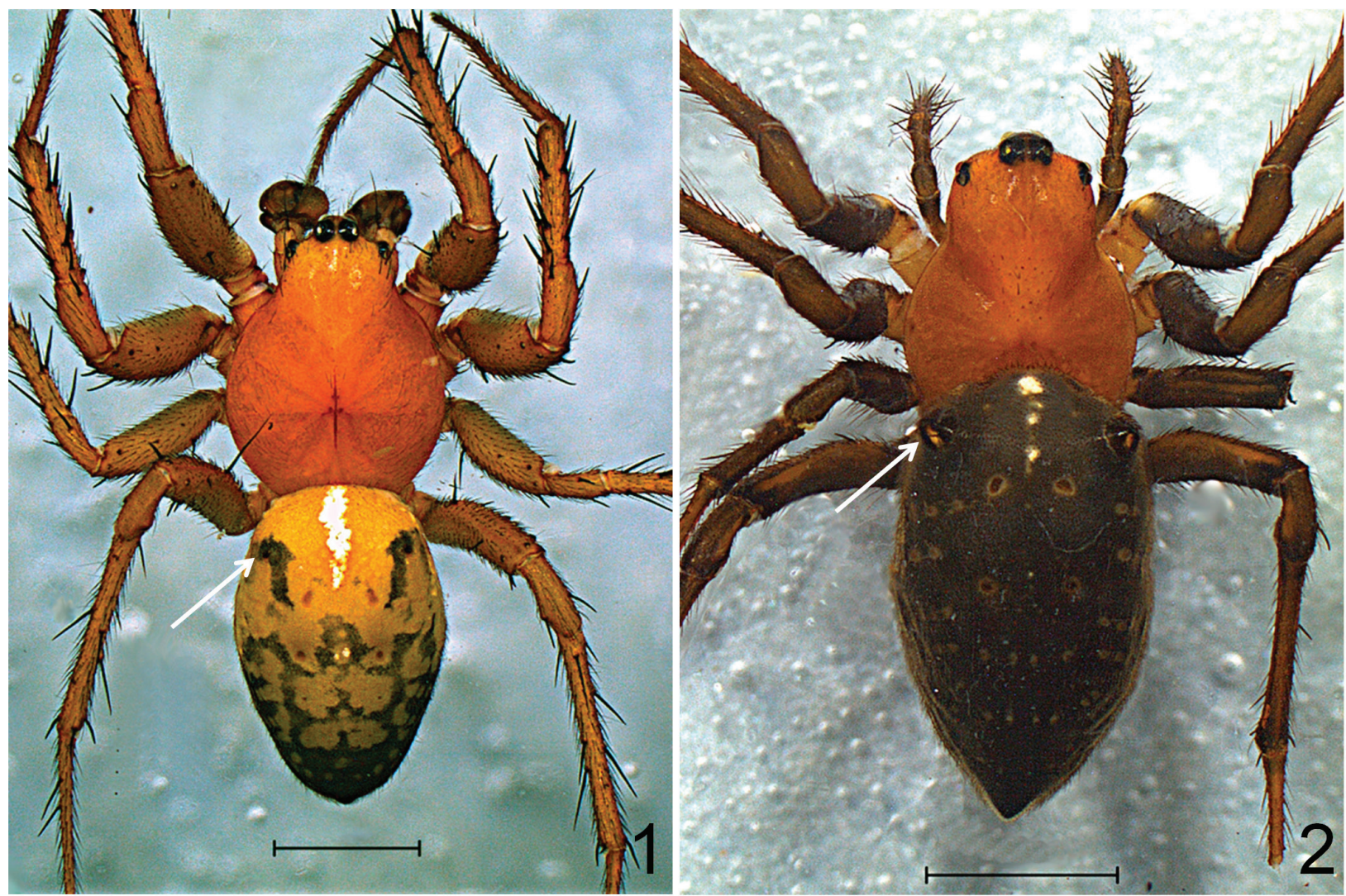

Figs 1-2. Alpaida clarindoi sp. nov.: 1, male, dorsal view; 2, female, dorsal view. Scale bars (mm): Fig. 1, 1.6; Fig. 2, 1.5. Shoulder spines indicated by arrows.

65²1'16.207'W); ふૈ, 30.VIII.2011, M. C. Silveira leg. (MZSP 39481); +, 30.VIII.2011, M. C. Silveira leg. (MZSP 39494), all from Mutum (9³6’34.380's; $\left.64^{\circ} 56^{\prime} 22.236^{\prime \prime} \mathrm{W}\right)$. The three localities mentioned are from Porto Velho, Rondônia, Brazil.

Etymology. The specific name is a tribute to Clarindo Alves Trindade (1952 - 2013), for his invaluable contributions in the fieldwork.

Diagnosis. The presence of a pair of shoulder spines distinguishes Alpaida clarindoi sp. nov. from most Alpaida species (Figs 1,2). Males of Alpaida clarindoi sp. nov. can be separated from the few species with similar shoulder spines by characteristics of the palpus (Figs 7-9). Alpaida graphica (O. Pickard-Cambridge, 1889) presents similar palpus features (LEVI 1988:451, fig. 439), but the tegulum is differently shaped and lack the apical pointed tip present in the males of $A$. clarindoi sp. nov. In A. banos Levi, 1988 (LEVI 1988:427, fig. 266) the pointed tip of the tegulum is located laterally rather than apically, and the terminal apophysis is not acuminated. Although devoid of shoulder spines, A. moata (Chamberlin \& Ivie, 1936) have a very similar palpus features (LEVI 1988:449, fig. 420), but its median apophysis is narrower and possess a pointed tip on the middle of its external border. Alpaida conica O. PickardCambridge, 1889 also have a similar palpus shape, but in this species the median apophysis possess a small spine in the corner close to the radix. Furthermore, as observed in A. banos, the pointed tip of the tegulum is located laterally rather than apically (LEVI 1988:463, figs 508-511).

The female is distinguished from other species with similar shoulder spines by the subquadrangular shape of the epyginum. The epyginum of $A$. cuyabeno Levi, 1988 (LeVI 1988:427, figs 267-268) and A. narino Levi, 1988 (LEVI 1988:427, figs 271-272) are more rounded than that of $A$. clarindoi sp. nov., in both ventral and dorsal views. Additionally, the scape of $A$. clarindo $i$ sp. nov. is triangular, while that of $A$. cuyabeno is rounded. Finally, although not possessing shoulder spines, females of $A$. moata also have a very similar colour pattern and genitalia, but the posterior median plate of the epyginum of $A$. moata has a dorsoventral median ridge (LEVI 1988:449, fig. 416), absent in $A$. clarindoi sp. nov.

Description. Male (holotype). Carapace, chelicerae and endites orange. Sternum orange with a central white mark, and labium orange with a white distal margin. Eyes ringed by black. Thoracic fovea cross-like. Dorsum of abdomen brownish with dark spots, increasingly darker in the posterior half, and presenting three anterior white marks, one central and two on side, lateral marks extending until approximately the half of the abdomen (Fig. 1). Ventral part of abdomen dark grey with two longitudinal parallel light bands. Shoulder of the abdomen with a pair of short spines (thorns, sensu LEVI, 1988), curved backwards. Legs orange, femur of the first two legs thickened, and tibia of the two first legs with long spines. Coxae of first leg with hook. Palpal patellae with one macrosetae. Palpus (Figs 7-9) 

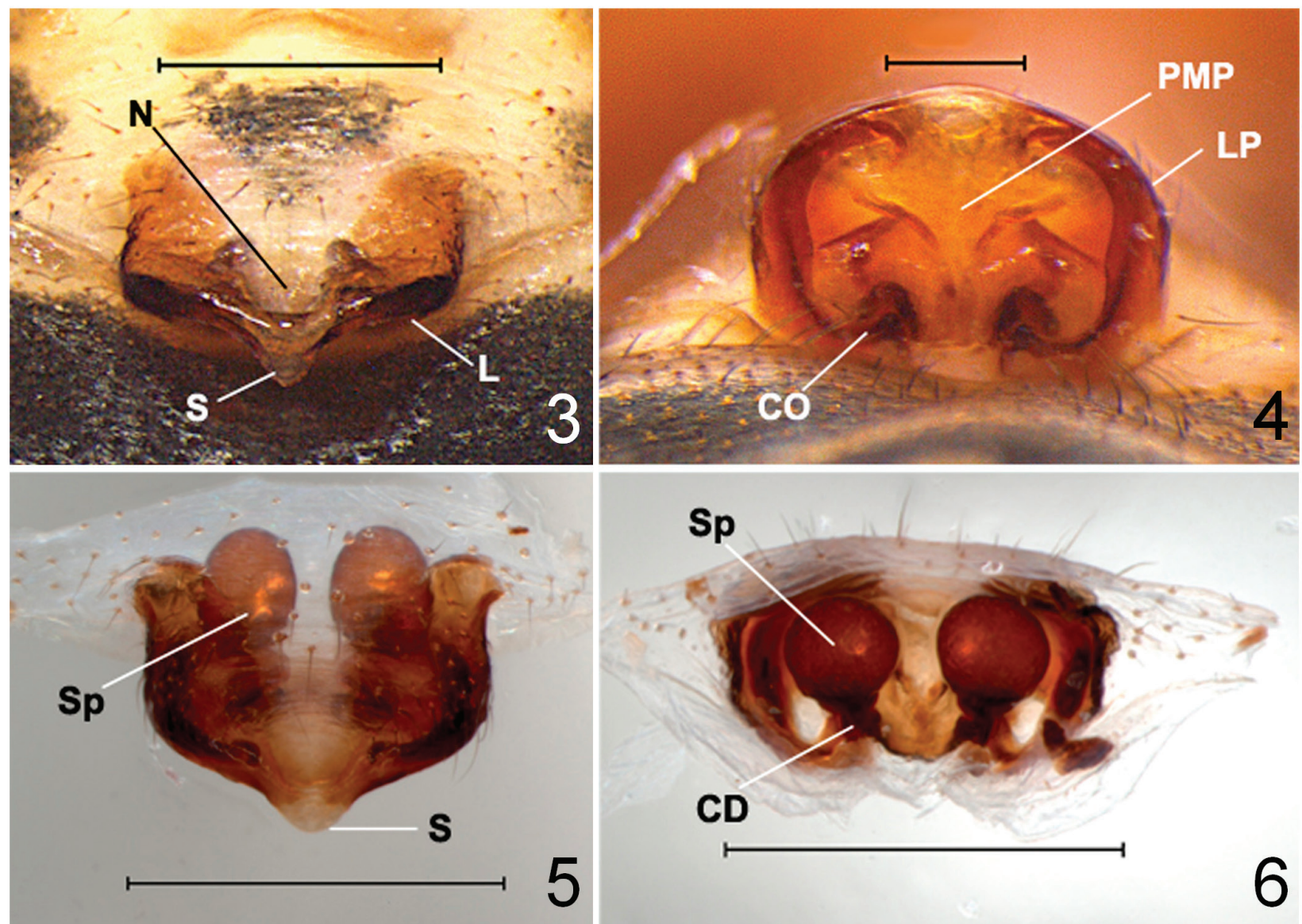

Figs 3-6. Alpaida clarindoi sp. nov.: 3, female epyginum, ventral view; 4, ditto, posterior view; 5, digested vulva, anteroventral view; 6, ditto, anterior view (CD, copulatory ducts; CO, copulatory openings; L, epyginal lips; LP, lateral plate; N, epyginal notch; PMP, posterior median plate; S, scape; Sp, spermathecal). Scale bars (mm): Fig. 3, 0.5; Fig. 4, 0.2; Figs 5, 6, 0.55.

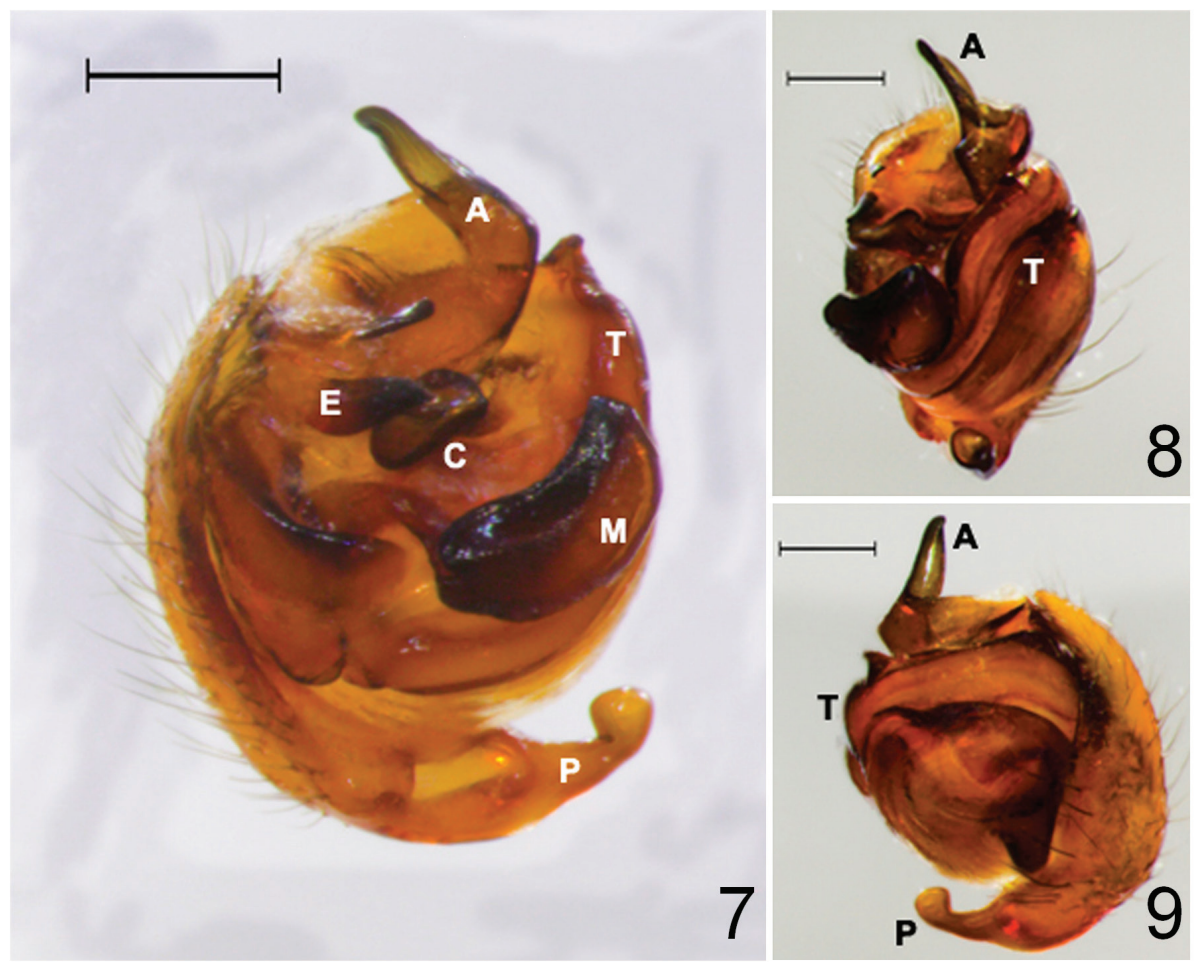

Figs 7-9. Alpaida clarindoi sp. nov. Male palpus: 7, mesal view; 8, ventral view; 9, ectal view (A, terminal apophysis; C, conductor; E, embolus; $\mathrm{M}$, median apophysis; P, paracymbium; T, tegulum). Scale bars (mm): Fig. 7, 0.2; Figs 8, 9, 0.33. 
with a short and thick embolus, edge of tegulum with an apical spine. Median apophysis slightly curved and terminal apophysis twisted and pointed upwards. Total length 6.5. Carapace length 2.7, width, 2.0. Abdomen length 3.8. First femur 3.1, patella and tibia 3.7, metatarsus 2.1, tarsus 0.9 . Second patella and tibia 2.7, third 1.9, fourth 2.7 .

Female (paratype, MZSP 34046). Colour pattern of the carapace similar as male, but legs present a darker orange coloration, except for the metatarsus and tarsus. Abdomen is almost entirely dark grey in dorsal view and dark gray with two longitudinal parallel light bands in ventral view, as in males. Carapace with few central setae. The abdomen shoulder spines are slightly larger than those of the male (Fig. 2). Epigynum subquadrangular in ventral view, presenting a triangular scape with a notch (Figs 3-6). Total length 7.6. Carapace length 3.1, width 2.4. Abdomen length 4.5. First femur 2.6, patella and tibia 3.1 , metatarsus 2.1, tarsus 0.9 . Second patella and tibia 2.7, third 1.6, fourth 2.7.

Variation. Total length of females varies from 6.2 to $8.9(n=14)$ and that of males from 5.0 to $6.5(n=2)$. The color of the abdomen may be lighter in some female individuals, with a brownish coloration in the anterior portion, more similar to the color pattern of the male. Carapace setae may vary in abundance and thickness.

Natural History. All specimens were captured at night, in the understory, in an area of dense tropical forest, at the margins of the Madeira River. Specimens were captured in four different distances from the border of the river: 50 $(\mathrm{n}=1), 1,050$ (10), 2,050 (4) and 4,050 m (1).

Distribution. Known only from the types localities.

Acknowledgments: We are grateful to anonymous reviewers and to the editor for the modifications proposed and to Dr. Ricardo Pintoda-Rocha for his suggestions and for providing logistical support. We also thank Humberto Yamaguti, Igor Cizauskas and Aline Benetti, for helping with the images. We are grateful to TETRAPLAN for the use of the material sampled during the monitoring campaign at Jirau, and to
Sabrina O. Jorge, coordinator of the arachnological survey. We are also grateful to the Zoology dept of the Instituto de Biociências, Universidade de São Paulo. The first author thanks FAPESP for a grant (2013/23736-2), and the second author was supported by a CNPq fellowship.

\section{REFERENCES}

Abrahim, N. \& Bonaldo, A. B. 2008. A new species of Alpaida (Araneae, Araneidae) from Caxiuanã National Forest, Oriental Amazonia, Brazil. Iheringia, Série Zoologia 98(3):397-399.

Braga-Pereira, J. F. \& Santos, A. J. 2013. Two new species of the spider genus Alpaida (Araneae: Araneidae) from restinga areas in Brazil. Zoologia 30(3):324-328.

Buckup, E. H. \& Meyer, A. C. 1993. Sobre o macho de Alpaida scriba (Araneae, Araneidae). Revista Brasileira de Entomologia 37(2):353354.

Buckup, E. H. \& Rodrigues, E. L. N. 2011. Espécies novas de Alpaida (Araneae, Araneidae), descrições complementares e nota taxonômica. Iheringia, Série Zoologia 101(3):262-267.

Deza, M. \& Andia, J. M. 2014. Two new species of the orb-weaving spider genus Alpaida (Araneae, Araneidae) from Peru. Zootaxa 3827(1):067-077.

Dierkens, M. 2014. Contribution à l'étude des Araneidae de Guyane française. V - Les genres Alpaida et Ocrepeira. Bulletin mensuel de la Societé Linnéenne de Lyon 83(1-2):14-30.

Levi, H. W. 1988. The Neotropical orb-weaving spiders of the genus Alpaida (Araneae: Araneidae). Bulletin of the Museum of Comparative Zoology 151(7):365-487.

. 1993. American Neoscona and corrections to previous revisions of neotropical orb-wavers (Araneae: Araneidae). Psyche 99(23):221-239.

Rodrigues, E. N. L. \& MendonçA, M. DE S. JR. 2011. Araneid orbweavers (Araneae, Araneidae) associated with riparian forests in southern Brazil: a new species, complementary descriptions and new records. Zootaxa 2759:60-68.

SAntos, K. P. \& SAntos, A. J. 2010 Two new species of the orb-weaving spider genus Alpaida from Brazil (Araneae: Araneidae). Zootaxa 2336:61-66.

Saturnino, R.; Rodrigues, B. V. B. \& Bonaldo, A. 2015. Alpaida (Araneae: Araneidae) from the Amazon Basin and Ecuador: new species, new records and complementary descriptions. Zoologia 32(3):241-256.

World Spider Catalog. 2015. World Spider Catalog. Version 16. Natural History Museum Bern. Available at $<\mathrm{http}: / /$ wsc.nmbe.ch>. Accessed on 30 September 2015. 